\title{
Differential effects of dexamethasone treatment on lipopolysaccharide-induced testicular inflammation and reproductive hormone inhibition in adult rats
}

\author{
R M Gow, M K O'Bryan, B J Canny ${ }^{1}$, G T Ooi ${ }^{2}$ and M P Hedger \\ Monash Institute of Reproduction and Development, Monash University, Clayton, Victoria 3168, Australia \\ ${ }^{1}$ Department of Physiology, Monash University, Clayton, Victoria 3168, Australia \\ ${ }^{2}$ Prince Henry's Institute of Medical Research, Clayton, Victoria 3168, Australia \\ (Requests for offprints should be addressed to M P Hedger, Monash Institute of Reproduction and Development, Monash Medical Centre, Clayton, \\ Victoria 3168, Australia; Email: mark.hedger@med.monash.edu.au)
}

\begin{abstract}
A single intraperitoneal injection of lipopolysaccharide (LPS) causes a biphasic suppression of testicular steroidogenesis in adult rats, with inhibition at $6 \mathrm{~h}$ and $18-24 \mathrm{~h}$ after injection. The inhibition of steroidogenesis is independent of the reduction in circulating $\mathrm{LH}$ that also occurs after LPS treatment, indicating a direct effect of inflammation at the Leydig cell level. The relative contributions to this inhibition by intratesticular versus systemic responses to inflammation, including the adrenal glucocorticoids, was investigated in this study.

Adult male Wistar rats (eight/group) received injections of LPS (0.1 mg/kg i.p.), dexamethasone (DEX; $50 \mu \mathrm{g} / \mathrm{kg}$ i.p.), LPS and DEX, or saline only (controls), and were killed $6 \mathrm{~h}, 18 \mathrm{~h}$ and $72 \mathrm{~h}$ later. Treatment with LPS stimulated body temperature and serum corticosterone levels measured $6 \mathrm{~h}$ later. Administration of DEX had no effect on body temperature, but suppressed serum corticosterone levels. At the dose used in this study, DEX alone had no effect on serum LH or testosterone at any time-point. Expression of mRNA for interleukin- $1 \beta$ (IL-1 $\beta$ ), the principal inflammatory cytokine, was increased in both testis and liver of LPS-treated rats. Serum $\mathrm{LH}$ and testosterone levels were considerably reduced at $6 \mathrm{~h}$ and $18 \mathrm{~h}$ after LPS treatment, and had not completely
\end{abstract}

recovered by $72 \mathrm{~h}$. At $6 \mathrm{~h}$ after injection, DEX inhibited basal IL-1 $\beta$ expression and the LPS-induced increase of IL-1 $\beta$ mRNA levels in the liver, but had no effect on IL- $1 \beta$ in the testis. The effects of DEX on IL- $1 \beta$ levels in the liver were no longer evident by $18 \mathrm{~h}$. In LPS-treated rats, DEX caused a significant reversal of the inhibition of serum $\mathrm{LH}$ and testosterone at $18 \mathrm{~h}$, although not at $6 \mathrm{~h}$ or $72 \mathrm{~h}$. Accordingly, DEX inhibited the systemic inflammatory response, but had no direct effect on either testicular steroidogenesis or intra-testicular inflammation, at the dose employed.

These data suggest that the inhibition of Leydig cell steroidogenesis at $6 \mathrm{~h}$ after LPS injection, which was not prevented by co-administration of DEX, is most likely due to direct actions of LPS at the testicular level. In contrast, the later Leydig cell inhibition (at $18 \mathrm{~h}$ ) may be attributable to extra-testicular effects of LPS, such as increased circulating inflammatory mediators or the release of endogenous glucocorticoids, that were inhibited by DEX treatment. These data indicate that the early and late phases of Leydig cell inhibition following LPS administration are due to separate mechanisms.

Journal of Endocrinology (2001) 168, 193-201

\section{Introduction}

Systemic inflammation due to infection or autoimmune diseases inhibits testicular steroidogenesis and spermatogenesis, leading to temporary or permanent fertility problems (Adamopoulos et al. 1978, Cutolo et al. 1988, Buch \& Havlovec 1991). Several laboratories, including our own, have investigated this process using animal models of inflammation induced by injections of lipopolysaccharide (LPS), a bacterial outer cell wall molecule that activates the inflammatory functions of monocytes and macrophages
(Wallgren et al. 1993, Refojo et al. 1998, O’Bryan et al. 2000). Inhibition of both anterior pituitary secretion of luteinizing hormone (LH) and Leydig cell testosterone secretion have been observed in these models. Recently, we demonstrated that a single injection of even a relatively low dose of LPS $(0 \cdot 1 \mathrm{mg} / \mathrm{kg})$ causes a biphasic decrease in serum and intratesticular testosterone concentrations in adult rats at $6 \mathrm{~h}$ (early phase) and at 18-24 h (late phase) after treatment, with an intervening period of partial recovery (O'Bryan et al. 2000). Although serum LH was also inhibited by higher doses of LPS, the decrease in 
testosterone was independent of changes in $\mathrm{LH}$, as confirmed by the inability of the Leydig cells to respond to a subsequent injection of exogenous human chorionic gonadotrophin. Systemic inflammation, therefore, has a direct inhibitory effect on testicular steroidogenesis, independent of the inhibition of gonadotrophin secretion at the hypothalamo-pituitary level.

The mechanism for this action of LPS on Leydig cell function in vivo is poorly defined. It has been shown that high doses of LPS cause down-regulation of Leydig cell synthesis of steroidogenic acute regulatory protein, the cholesterol side-chain cleavage enzyme (P450scc) and 17 $\alpha$-hydroxysteroid/17-20-lyase (P450c17) in vivo (Hales et al. 1992, Bosmann et al. 1996). Furthermore, several inflammatory mediators, including interleukin-1 $\beta$ (IL-1 $\beta$ ), tumour necrosis factor- $\alpha$ (TNF $\alpha$ ) and nitric oxide, inhibit Leydig cell steroidogenesis by similar mechanisms in vitro (Lin et al. 1991, 1998, Li et al. 1995, Del Punta et al. 1996, Mauduit et al. 1998). The increased production of these inflammatory mediators both within the testis and in the systemic circulation is likely to have a significant inhibitory effect on Leydig cell function. Indirect effects of inflammation on the testis have also been implicated, including interference with the testicular blood flow (Bergh \& Söder 1990, Sharma et al. 1998), and inhibition mediated by inflammation-sensitive neural pathways from the central nervous system to the testis (Turnbull \& Rivier 1997, Ogilvie et al. 1999).

Significantly, production of inflammatory cytokines also activates the hypothalamic-pituitary-adrenal axis resulting in increased production of glucocorticoids (reviewed by Imura et al. 1991). Glucocorticoids exert a negative feedback effect on the inflammatory response by reducing the production, secretion and actions of the principal inflammatory mediators, such as IL- $1 \beta$, and are widely used clinically as anti-inflammatory agents (Kapcala et al. 1995). However, glucocorticoids also inhibit testicular steroidogenesis by actions at the hypothalamus and pituitary (Bambino \& Hsueh 1981), and by direct inhibition of P450scc, 3 $\beta$-hydroxysteroid dehydrogenase and P450c17 levels (Sapolsky 1985, Hales \& Payne 1989, Monder et al. 1994, Gao et al. 1996), acting through specific receptors on the Leydig cells (Stalker et al. 1989). Glucocorticoid levels are elevated for 4-6 h following LPS treatment in humans and experimental animals (Wolff 1973, Stenzel-Poore et al. 1993). As a consequence of these separate effects on both inflammation and Leydig cell function, the role of glucocorticoids in LPS-mediated inhibition of Leydig cell is difficult to anticipate. Glucocorticoids may mediate the suppression of testosterone concentrations in this model (Cumming et al. 1983). Conversely, production of glucocorticoids should inhibit the inflammatory response and inflammatory mediator production, and may limit the resulting effect on Leydig cell function and damage to the seminiferous epithelium. The aim of the present study, therefore, was to identify the respective contributions of intratesticular and systemic inflammatory responses, and the adrenal glucocorticoids, in the inhibition of testicular steroidogenesis following LPS administration. This involved examining the effect of administration of the glucocorticoid, dexamethasone, at a dose that inhibits systemic inflammatory responses, on LPS-induced inhibition of the hypothalamo-pituitarytestis axis in adult rats. In this study, IL- $1 \beta$ mRNA expression was used as a specific marker of tissue-specific inflammation, and the liver was used as a control tissue for systemic (i.e. extratesticular) inflammation.

\section{Materials and Methods}

\section{Reagents}

LPS (from E. coli, serotype 0127.B8) and testosterone were obtained from Sigma Chemical Co. (St Louis, MO, USA). Dexamethasone sodium phosphate (DEX) was obtained from David Bull Laboratories (Victoria, Australia). Reagents for the LH radioimmunoassay (RIA) were supplied by the National Institute of Diabetes and Digestive and Kidney Diseases (Bethesda, MD, USA). The restriction enzymes, XbaI, EcoRI, HindIII, were obtained from Promega Corporations (Madison, WI, USA). The rat $1161 \mathrm{bp}$ IL-1 $\beta$ cDNA plasmid was generously provided by Dr D Nikolic-Paterson (Department of Nephrology, Monash Medical Centre, Clayton, Australia). $\left[\alpha^{32} \mathrm{P}\right] \mathrm{dCTP}$ was obtained from Amersham Pharmacia Biotech (Amersham, Bucks, UK).

\section{Animals and treatments}

Outbred adult male Wistar rats (80-100 days old) weighing 300-330 g were housed three per cage, fed standard rat chow and water ad libitum and maintained at an ambient temperature of $22-25{ }^{\circ} \mathrm{C}$ under standard lighting regimens (12 h light:12 h darkness, lights on at $0700 \mathrm{~h}$ ). Experimental procedures were approved by the Monash University Standing Committee on Ethics in Animal Experimentation and conformed to the National Health and Medical Research Council/Commonwealth Scientific and Industrial Research Organisation/Australian Agricultural Council Code of Practice for the Care and Use of Animals for Experimental Purposes. For 7 days prior to the experiment, the rats were handled daily, for approximately $2-5 \mathrm{~min}$, rectal temperatures were measured and body weights were recorded. This was undertaken in order to acclimatise the rats to their surrounding environment and human contact, and to decrease any hypothalamo-pituitary-adrenal axis responses to the handling involved in the subsequent experimental manipulations (Ma \& Lightman 1998). Rats were randomly divided into four treatment groups, control $(n=8)$, LPS treated $(n=8)$, DEX treated $(n=8)$, and LPS 
and DEX treated $(n=8)$. Intraperitoneal injections of LPS at $0.1 \mathrm{mg} / \mathrm{kg}$ body weight in endotoxin-free saline and DEX at $50 \mu \mathrm{g} / \mathrm{kg}$ body weight were given to the appropriate rats at $1200 \mathrm{~h}$, and rats were accordingly killed at $1800 \mathrm{~h}$ (6 h group), $0600 \mathrm{~h}$ (18 h group) and $1200 \mathrm{~h} \mathrm{(72} \mathrm{h}$ group). Control groups received injections of saline and were included at each time-point because of significant circadian rhythms in testosterone and LH (Mock et al. 1978, O'Bryan et al. 2000). The dose of DEX used in this study was able to prevent death in adrenalectomised rats injected with $0.1 \mathrm{mg} / \mathrm{kg}$ LPS (our unpublished data), and was consistent with doses used to protect against the inflammatory actions of LPS in rats in previous studies (Nakano et al. 1987, Kapcala et al. 1995). This dose of DEX also significantly inhibits the adrenocorticotrophic hormone response to stress, and decreases plasma corticosteroid-binding globulin concentrations and thymic weight, which are established markers of integrated glucocorticoid exposure (Bradbury et al. 1994, Gomez et al. 1998).

Rats were anaesthetised with ether (BDH Laboratory Supplies, Poole, Dorset, UK) and a midline incision was made along the ventral surface. Blood $(6-8 \mathrm{ml})$ was collected via cardiac puncture into uncoated tubes and the serum was separated by centrifugation at $3000 \mathrm{~g}$ for $10 \mathrm{~min}$. The serum was stored frozen at $-20^{\circ} \mathrm{C}$ until used for hormone analysis. One testis and a lobe of liver were collected for mRNA analysis. These tissues were snap frozen in dry ice and ethanol and stored at $-70{ }^{\circ} \mathrm{C}$ until needed.

\section{Hormone assays}

Serum LH concentrations were measured using a specific double-antibody RIA (Sun et al. 1990). Serum testosterone levels were measured using a direct double-antibody RIA as described previously (O'Donnell et al. 1994). Serum corticosterone concentrations were measured using a direct, double-antibody, ${ }^{125}$ I RIA kit supplied by ICN Biomedicals (Costa Mesa, CA, USA) which has been validated for use with serum from rats and mice. All samples were measured in a single assay, which was conducted according to the manufacturer's instructions; the values of the quality control samples were within the recommended range.

\section{Northern blot analysis}

Total cellular RNA was extracted from control and treated testis and liver using the acid guanidinium thiocyanatephenol-chloroform method of Chomczynski \& Sacchi (1987). Samples of RNA $(15 \mu \mathrm{g})$ were denatured in loading buffer $(33 \%$ formamide, $14 \%$ formaldehyde, $0.05 \%$ bromophenol blue, $0.05 \%$ xylene cyanol and $80 \mu \mathrm{g}$ ethidium bromide) and size fractionated on a $1.2 \%$ agarose-formaldehyde gel by electrophoresis in $1 \times 3$ -
(N-morpholino)propoanesulfonic acid buffer. The RNA was transferred onto Hybond $\mathrm{N}$ nylon membranes (Amersham Pharmacia Biotech) by capillary transfer, and the membranes were cross-linked using u.v. light at $125 \mathrm{~mJ} / \mathrm{m}^{2}$ (GS Gene Linker; Bio-Rad Laboratories, Richmond, CA, USA) (Church \& Gilbert 1984, Khandjian \& Meric 1986) and baked for $60 \mathrm{~min}$ at $80{ }^{\circ} \mathrm{C}$. The rat IL-1 $\beta$ (1161 bp) cDNA probe was excised from a pMOSBlueT-vector using $\mathrm{XbaI}$ and EcoRI restriction enzymes and gel purified using QIAquick gel extraction kit (Qiagen, Hilden, Germany) according to the manufacturer's instructions. Rat glyceraldehyde-3-phosphate dehydrogenase (GAPDH) was used as a housekeeping gene to monitor RNA loading equality between samples and was prepared from a partial rat $(650 \mathrm{bp})$ cDNA using EcoRI and HindIII. The cDNA probes were labelled by random priming using $\left[\alpha^{32} \mathrm{P}\right] \mathrm{dCTP}$ in the RTS RadPrime DNA labelling system (Life Technologies, Gaithersburg, MD, USA). Unincorporated nucleotides were removed using ProbeQuant ${ }^{\mathrm{TM}}$ G-50 Micro Columns (Amersham Pharmacia Biotech). Blots were prehybridised for $2 \mathrm{~h}$ at $50{ }^{\circ} \mathrm{C}$ with hybridisation buffer $(50 \%$ formamide, $10 \%$ dextran sulfate, $5 \times \mathrm{SSPE}, 10 \times$ Denhardt's, $100 \mu \mathrm{g} / \mathrm{ml}$ salmon sperm DNA, 1\% sodium dodecyl sulfate). The blots were then hybridised overnight in fresh hybridisation buffer at $50{ }^{\circ} \mathrm{C}$ with $10^{6}$ c.p.m. $/ \mathrm{ml}$ of the labelled cDNA probe. The blots were washed to a maximum stringency of $0 \cdot 1 \times$ SSPE for $15 \mathrm{~min}$ at $60^{\circ} \mathrm{C}$. The blots were exposed to Kodak Biomax MR film (Kodak, Rochester, NY, USA) with an intensifying screen at $-70^{\circ} \mathrm{C}$ for $2 \mathrm{~h}$ (GAPDH), and $70 \mathrm{~h}$ or $170 \mathrm{~h}$ (IL-1 $\beta$ ). Blots were quantified using an FLA 2000 Phosphorimager analyser (Fujix, Berthold, Australia) and analysed using Macintosh MacBAS version $2 \cdot 4$ software supplied by the manufacturer. Some samples with degraded RNA were excluded from the study, as indicated in the figure legends. After background subtraction, the density of each IL-1 $\beta$ transcript band was normalised for loading differences as a ratio against the GAPDH band for the corresponding sample.

\section{Statistical analysis}

Data were analysed using SPSS for Windows (version 7; SPSS Inc., Cary, NC, USA). All analyses were performed using a general factorial two-way analysis of variance (ANOVA), with treatment with LPS and DEX as the main factors. The data were analysed for homogeneity of variance using Levene's test, and square root or logtransformation was undertaken when necessary. When significant interactions between the main factors occurred, differences between individual means were calculated using Fisher's least significant difference test. Results are expressed as means \pm S.E.M.and significance was defined as $P<0 \cdot 05$. 


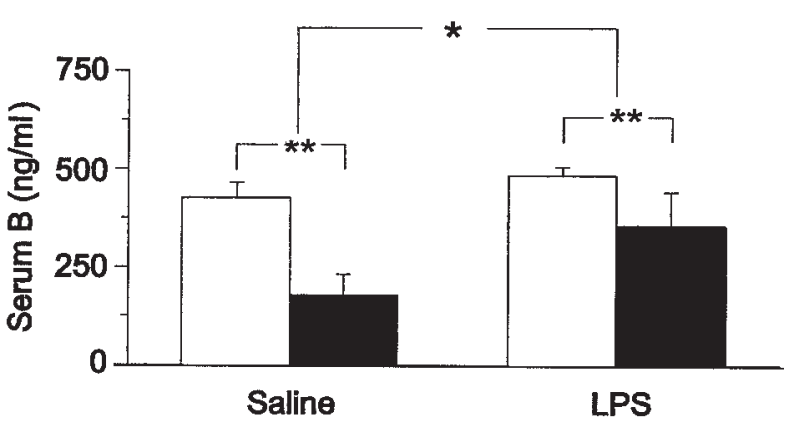

Figure 1 The effect of LPS and DEX on serum corticosterone (B) concentrations $6 \mathrm{~h}$ after treatment in rats (means \pm S.E.M., $n=8$ /group) injected with saline or LPS $(0 \cdot 1 \mathrm{mg} / \mathrm{kg}$ i.p. $)$ in combination with saline (open bars) or DEX (solid bars, $50 \mu \mathrm{g} / \mathrm{kg}$ i.p.). ${ }^{*} P<0 \cdot 05$ LPS vs saline treatment; ${ }^{* *} P<0 \cdot 01$ DEX vs saline treatment.

\section{Results}

\section{General observations}

Rats that received LPS showed physical signs of general inflammation, including piloerection and shivering. The extent of these signs appeared to be less in the rats treated with both LPS and DEX, when compared with those receiving LPS alone, although these effects were not quantified. Any physical signs had resolved by $12-18 \mathrm{~h}$ after LPS administration. Rectal temperatures measured $6 \mathrm{~h}$ after treatment were elevated in rats receiving LPS alone $\left(38.2 \pm 0 \cdot 2{ }^{\circ} \mathrm{C}\right)$, when compared with vehicletreated rats $\left(37 \cdot 6 \pm 0 \cdot 1{ }^{\circ} \mathrm{C}, P<0 \cdot 05\right)$. This LPS-induced increase in rectal temperature was prevented by the co-administration of DEX $(37 \cdot 9 \pm 0 \cdot 1, P>0 \cdot 05$ vs control), although DEX alone had no effect on rectal temperature $\left(37.5 \pm 0 \cdot 2{ }^{\circ} \mathrm{C}, P>0 \cdot 05\right.$ vs control). At 18 and $72 \mathrm{~h}$ after injection, no treatment had any significant effect on rectal temperature.

In order to confirm the action of LPS and DEX in modulating the hypothalamo-pitutary-adrenal axis, the concentration of corticosterone in the serum was measured in those animals killed $6 \mathrm{~h}$ after treatment. Corticosterone concentrations were increased in the LPS-treated animals $(P<0 \cdot 05)$, while administration of DEX significantly decreased $(P<0 \cdot 01)$ the secretion of the endogenous glucocorticoid (Fig. 1).

\section{Serum LH and testosterone concentrations}

The effects of LPS and DEX treatment on serum LH and testosterone concentrations are shown in Figs 2 and 3. At $6 \mathrm{~h}$ following injection, LPS caused a significant decrease in serum LH $(P<0 \cdot 01)$ and testosterone $(P<0 \cdot 01)$ to less than $50 \%$ of control levels, while the administration of DEX was without effect on hormone concentrations. By $18 \mathrm{~h}$ following injection there was a significant statistical
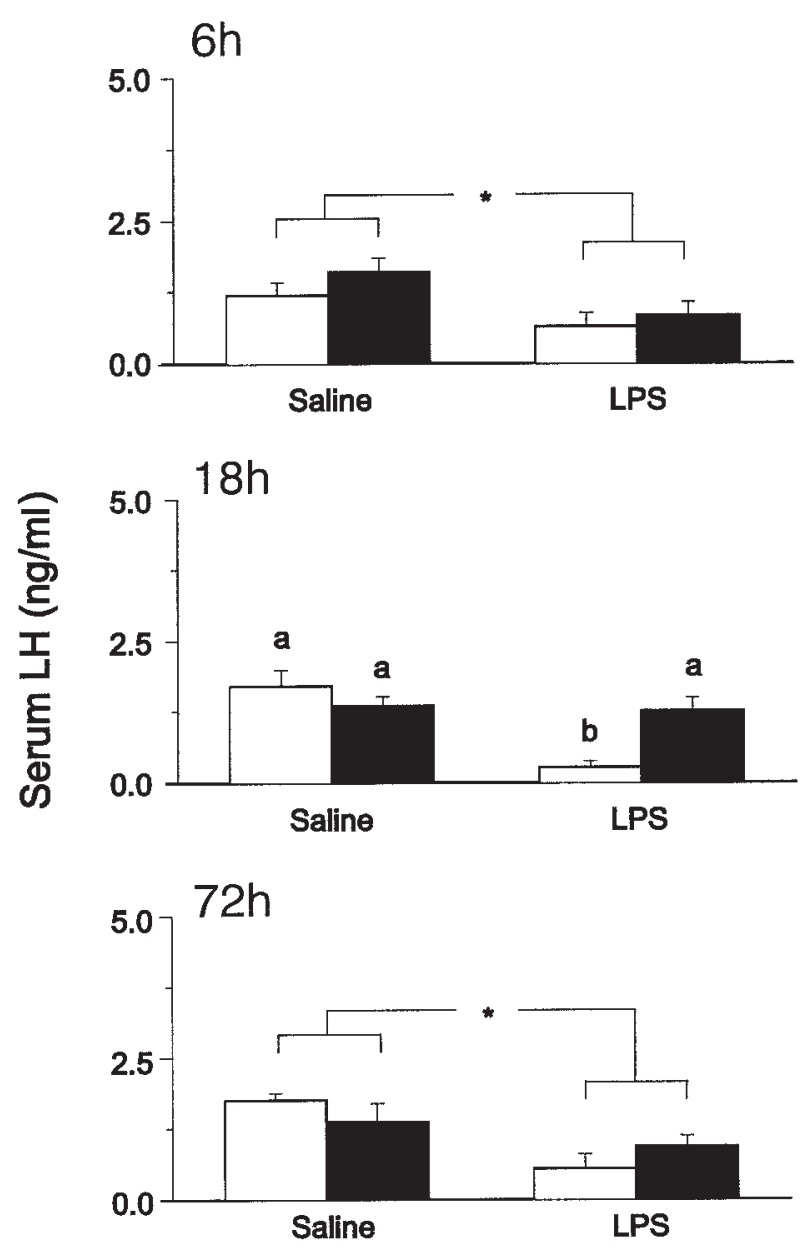

Figure 2 The effect of LPS and DEX on serum LH concentrations $6 \mathrm{~h}$ (upper panel), $18 \mathrm{~h}$ (middle panel) or $72 \mathrm{~h}$ (lower panel) after treatment in rats (means \pm S.E.M., $n=8$ /group) treated with saline or LPS $(0 \cdot 1 \mathrm{mg} / \mathrm{kg}$ i.p.) in combination with saline (open bars) or DEX (solid bars, $50 \mu \mathrm{g} / \mathrm{kg}$ i.p.). Upper and lower panels: ${ }^{*} P<0 \cdot 01$ LPS vs saline treatment; middle panel: bars with different lower case letters are significantly $(P<0 \cdot 05)$ different from each other.

interaction $(P<0 \cdot 05)$ between the effect of LPS and DEX on serum LH and testosterone concentrations. When compared with vehicle-treated controls, the concentrations of both hormones remained decreased $(P<0 \cdot 05)$ in the animals treated with LPS alone, while the concomitant administration of DEX was able to significantly $(P<0 \cdot 05)$ attenuate the LPS-induced decrease in the concentrations of both $\mathrm{LH}$ and testosterone. The concentrations of both hormones in the animals receiving both LPS and DEX were not different from those obtained in the vehicletreated animals, while DEX, when given alone, had no significant effect on hormone concentrations. At $72 \mathrm{~h}$ following treatment, the concentrations of both $\mathrm{LH}$ and testosterone were significantly decreased $(P<0 \cdot 01)$ in the 

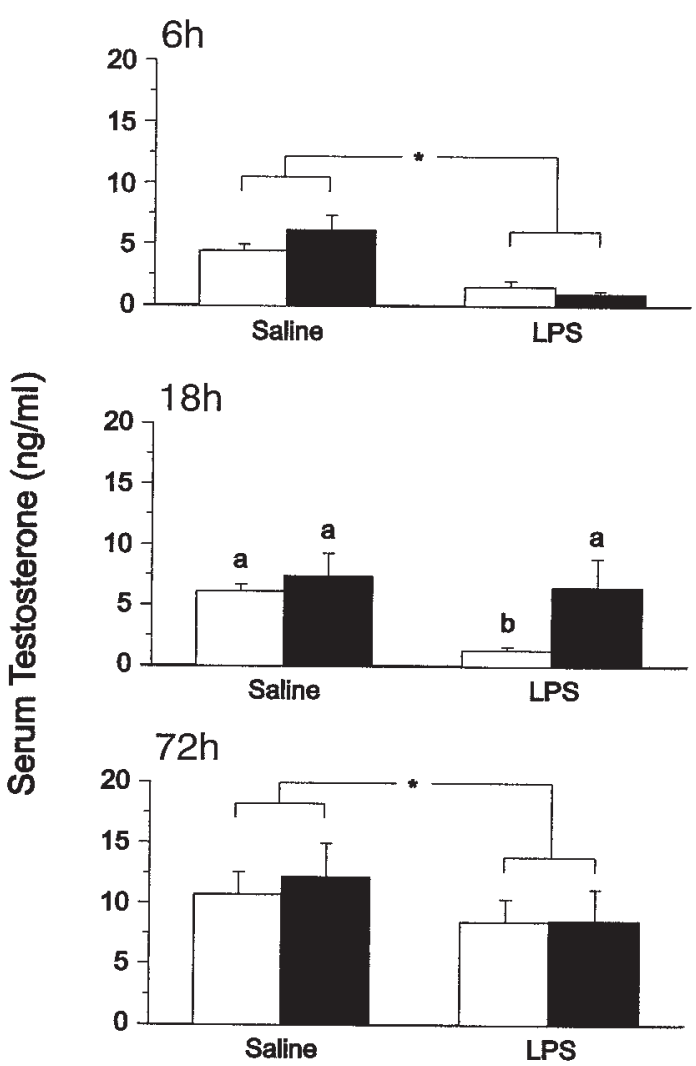

Figure 3 The effect of LPS and DEX on serum testosterone concentrations $6 \mathrm{~h}$ (upper panel), $18 \mathrm{~h}$ (middle panel) or $72 \mathrm{~h}$ (lower panel) after treatment in rats (means \pm S.E.M., $n=8 /$ group) treated with saline or LPS $(0 \cdot 1 \mathrm{mg} / \mathrm{kg}$ i.p. $)$ in combination with saline (open bars) or DEX (solid bars, $50 \mu \mathrm{g} / \mathrm{kg}$ i.p.). Upper and lower panels: ${ }^{*} P<0 \cdot 01$ LPS vs saline treatment; middle panel: bars with different lower case letters are significantly $(P<0 \cdot 05)$ different from each other.

animals treated with LPS, whereas DEX was without significant effect.

\section{$I L-1 \beta m R N A$ levels in the liver and testis}

Representative examples of Northern blot analyses of the relative amounts of IL-1 $\beta$ and GAPDH mRNAs in the liver and testis following $6 \mathrm{~h}$ and $18 \mathrm{~h}$ of the various treatments are shown in Figs 4 and 5. Barely detectable levels of IL-1 $\beta$ were observed in testis or liver samples from saline-treated control rats after $70 \mathrm{~h}$ of film exposure (Fig. 4), but were clearly evident at a longer exposure time (170 h, Fig. 5). The analysis revealed a transcript of $1.3 \mathrm{~kb}$, consistent with the previously published size of rat IL-1 $\beta$ mRNA (Zuckerman et al. 1989). Six hours after administration, LPS caused a significant increase $(P<0 \cdot 01)$ in IL-1 $\beta$ mRNA in both the testis and liver (Fig. 4). Administration of DEX inhibited $(P<0 \cdot 05)$ expression of IL-1 $\beta$ in the livers of saline- and LPS-treated animals, but had no significant effect on expression of IL-1 $1 \beta$ in the testes (Fig. 4). By $18 \mathrm{~h}$ after treatment, DEX was without significant effect on IL-1 $\beta$ mRNA expression in either the liver or testis, whereas LPS-stimulated IL-1 $\beta$ expression remained significantly elevated $(P<0 \cdot 01)$ in both organs (Fig. 5).

\section{Discussion}

Previously, we have shown that intraperitoneal injection of LPS causes a biphasic suppression of testosterone secretion, through direct inhibition of Leydig cell function, with phases of inhibition at $6 \mathrm{~h}$ and at 18-24 $\mathrm{h}$ after LPS administration (O'Bryan et al. 2000). In the present study, it has been shown that these effects were accompanied by an increase in IL-1 $\beta$ mRNA in the testis and liver, indicating both a local testicular and a systemic inflammatory response to LPS. Co-administration of the antiinflammatory glucocorticoid, DEX, inhibited the systemic inflammatory response to LPS, as indicated by liver IL-1 $\beta$ expression and endogenous corticosteroid levels, for at least the first $6 \mathrm{~h}$. On the other hand, DEX did not prevent the local inflammatory response (i.e. increased IL- $1 \beta$ production) in the testis. Significantly, DEX neither enhanced nor prevented the inhibition of testosterone levels at $6 \mathrm{~h}$ after LPS treatment, but reversed the effects of LPS on serum testosterone concentrations at the later timepoint $(18 \mathrm{~h})$. These data indicate that inhibiting systemic cytokine responses does not reverse the early downregulation of Leydig cell function after LPS administration. Consequently, this phase of inhibition of the Leydig cell is most likely the result of intratesticular inflammatory events stimulated by LPS, which were not affected by DEX treatment, such as the local up-regulation of proinflammatory cytokines including IL-1 $\beta$ and TNF $\alpha$, or even a direct effect of LPS on the Leydig cell itself (Hales et al. 1992, Lin et al. 1993, Bosmann et al. 1996). However, the longer-term inhibition of Leydig cell steroidogenesis observed at 18-24 h after LPS treatment appears to be due to effects of LPS that were inhibited by DEX, such as systemic up-regulation of inflammatory mediators or adrenal glucocorticoids. These data indicate that the early and late phases of Leydig cell inhibition following LPS administration are due to separate mechanisms, and this should be considered in all future investigations of inflammation-induced inhibition of testicular function.

In the present study, serum LH levels were reduced at all experimental time-points following LPS treatment. This was in contrast to one of our previous studies, where LH was largely unaffected using the same LPS batch and dose, and was only inhibited at higher doses of LPS (O'Bryan et al. 2000). Since Wistar rats were used in the present study, while Sprague-Dawley rats were used in the earlier study, these data may be attributable to 
Testis

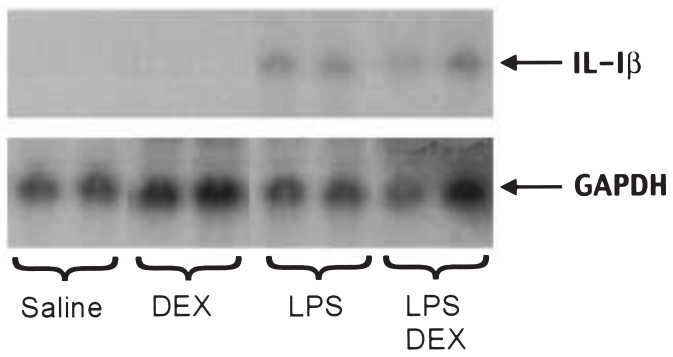

Liver
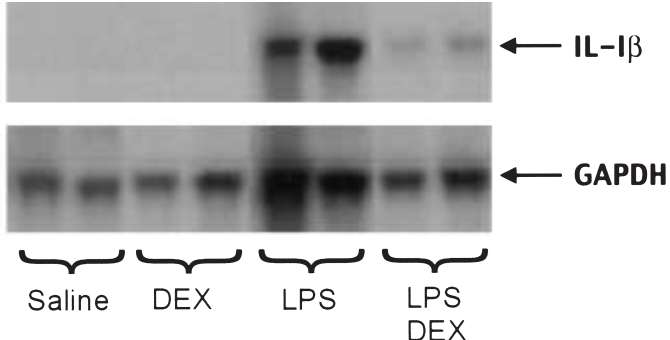
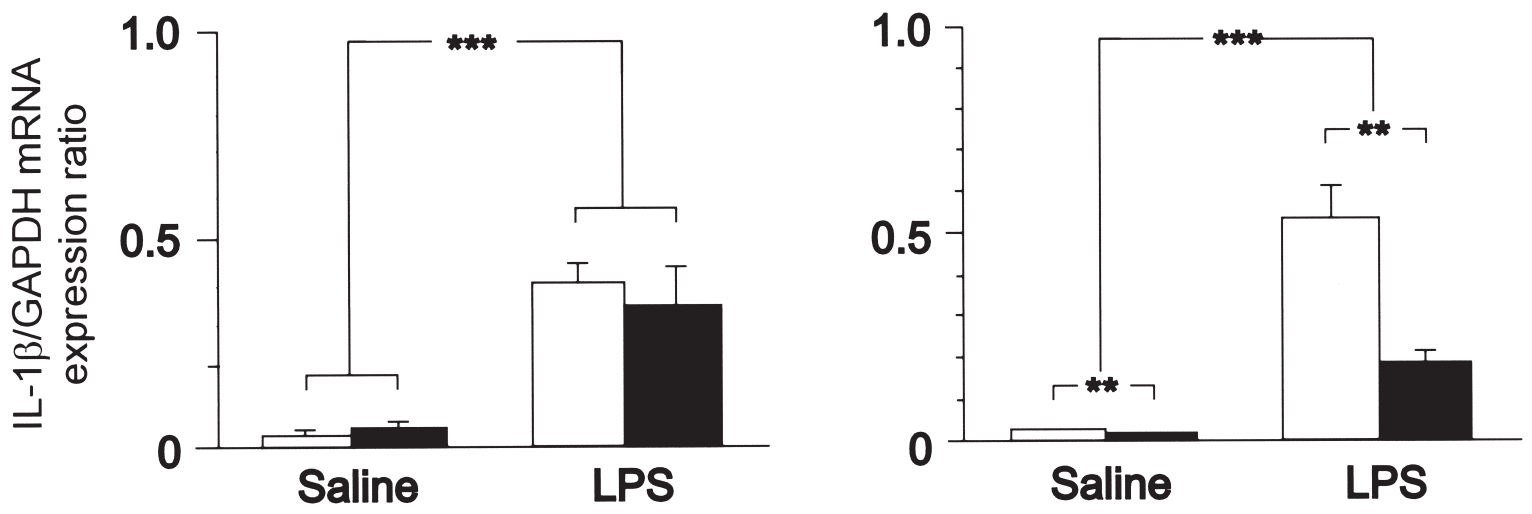

Figure 4 The effect of LPS and DEX on IL-1 $\beta$ mRNA in the testis and liver $6 \mathrm{~h}$ after treatment. Upper panels: representative duplicate examples of a Northern blot of IL-1 $\beta$ and GAPDH mRNAs in the testis (left panel) and liver (right panel) $6 \mathrm{~h}$ after treatment with saline or LPS $(0 \cdot 1 \mathrm{mg} / \mathrm{kg}$ i.p.) in combination with saline or DEX $(50 \mu \mathrm{g} / \mathrm{kg}$ i.p.). Lower panels: relative expression of IL- $1 \beta$ mRNA in the testis (left panel) and liver (right panel) of rats (means \pm S.E.M., $n=7-8 /$ group) $6 \mathrm{~h}$ after treatment with saline or LPS $(0 \cdot 1 \mathrm{mg} / \mathrm{kg}$ i.p.) in combination with saline (open bars) or DEX (solid bars, $50 \mu \mathrm{g} / \mathrm{kg}$ i.p.). ${ }^{* *} P<0 \cdot 01$ DEX vs saline treatment; ${ }^{* \star *} P<0 \cdot 001$ LPS vs saline treatment.

differences in sensitivity to LPS in the periphery between the two rat strains. Alternatively, since stress minimisation was not employed in the previous study, there may have been a reduction in experimental sensitivity, due to handling stress-induced reduction in endogenous LH levels (Rivier et al. 1986). In any case, the data underline the importance of measuring both testosterone and $\mathrm{LH}$ in any inflammatory model of testicular function.

Regardless of the pituitary response to LPS, however, it has already been demonstrated that the suppression of testosterone following LPS treatment is due to a direct inhibition of the Leydig cell, rather than an effect on serum LH (O'Bryan et al. 2000). The failure of DEX to inhibit testosterone production in the current model, even though it suppressed both liver IL-1 $\beta$ expression and endogenous corticosteroid levels, suggests that glucocorticoids are not responsible for the initial phase of testosterone suppression after LPS treatment (i.e. at $6 \mathrm{~h}$ ) and that this inhibition was more likely due to local inflammatory events that were not affected by DEX treatment. On the other hand, treatment with DEX did bring about a more rapid recovery in both serum testosterone and LH concentrations evident by $18 \mathrm{~h}$ after LPS administration. In contrast to the early phase, the later inhibition of testos- terone might be attributable to the systemic inflammatory response, including up-regulation of circulating inflammatory mediators or adrenal corticosteroids exerting a secondary effect at the testicular level. The serum LH data also indicate that a similar pattern of inhibition by local inflammatory events, followed by longer-term systemic inflammatory effects, may have occurred at the hypothalamo-pituitary level as well.

The dose of DEX employed in this study was chosen on the basis of inhibition of the inflammatory and stress responses in previously published studies (Nakano et al. 1987, Bradbury et al. 1994, Kapcala et al. 1995, Gomez et al. 1998). That this dose was effective was confirmed by the inhibition of basal and LPS-stimulated IL- $1 \beta$ production in the liver. A significant inhibition of serum corticosterone was also observed, even though the control levels of corticosterone appeared to be artificially elevated, most likely as a consequence of ether-induced stress at the time of death. Normal serum corticosterone concentrations in rats are generally in the order of 100$150 \mathrm{ng} / \mathrm{ml}$, rising to above $500 \mathrm{ng} / \mathrm{ml}$ upon application of stress (Bradbury et al. 1991). In spite of the profound inhibition of inflammation and adrenal responses, however, DEX alone appeared to have little or no direct effect 


\section{Testis}

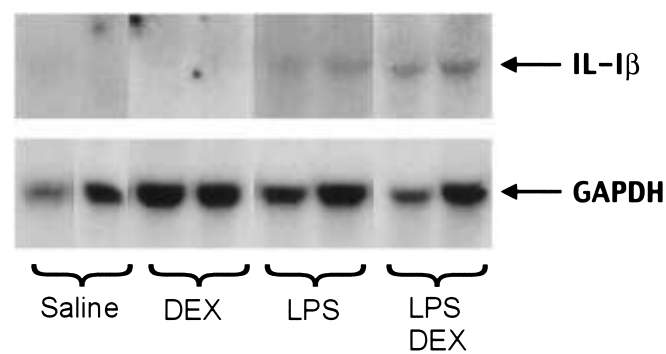

Liver

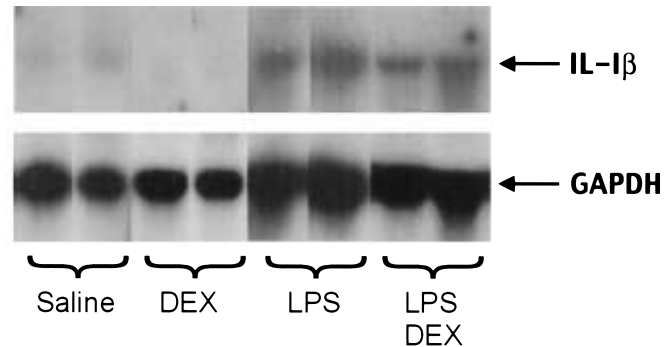

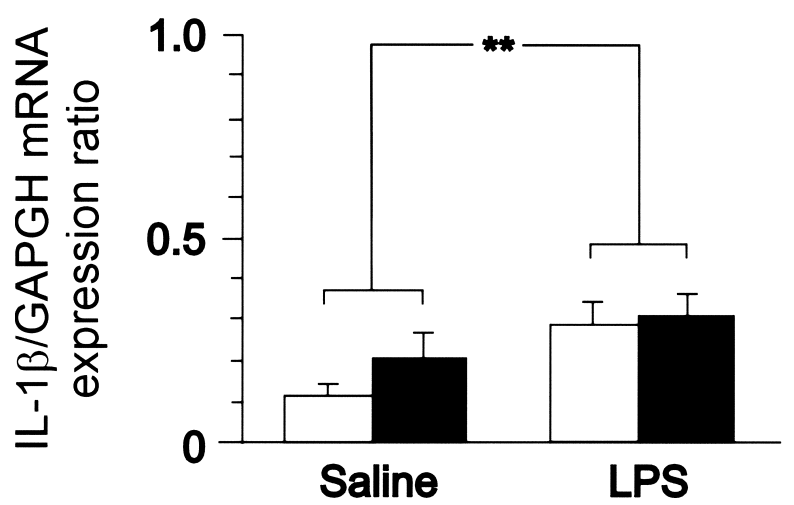

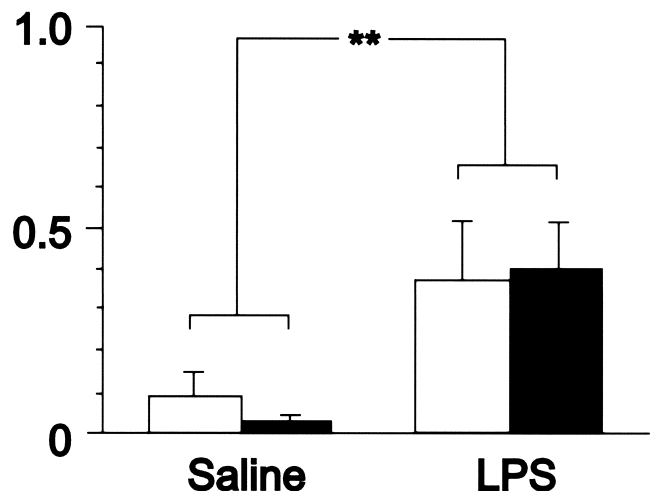

Figure 5 The effect of LPS and DEX on IL-1 $\beta$ mRNA in the testis and liver $18 \mathrm{~h}$ after treatment. Upper panels: representative duplicate examples of a Northern blot of IL-1 $\beta$ and GAPDH mRNAs in the testis (left panel) and liver (right panel) $18 \mathrm{~h}$ after treatment with saline or LPS $(0 \cdot 1 \mathrm{mg} / \mathrm{kg}$ i.p.) in combination with saline or DEX $(50 \mu \mathrm{g} / \mathrm{kg}$ i.p.). Lower panels: relative expression of IL- $1 \beta \mathrm{mRNA}$ in the testis (left panel) and liver (right panel) of rats (means \pm S.E.M., $n=5-8 /$ group) $18 \mathrm{~h}$ after treatment with saline or LPS $(0 \cdot 1 \mathrm{mg} / \mathrm{kg}$ i.p.) in combination with saline (open bars) or DEX (solid bars, $50 \mu \mathrm{g} / \mathrm{kg}$ i.p.). ${ }^{*} P<0 \cdot 01 \mathrm{LPS}$ vs saline treatment.

on the hypothalamo-pituitary-Leydig cell axis. Glucocorticoids, including DEX, have been shown to inhibit testicular steroidogenesis in rats in vivo when administrated at high doses or for extended periods (Saez et al. 1977, Lerman et al. 1997); however, the single dose used in the present study appears to have been below the threshold necessary to exert a detectable effect at the Leydig cell level.

Since the animals used in this study were not held under pathogen-free conditions, it is not surprising that constitutive expression of endogenous IL-1 $\beta$ production should have been detected in these animals - this is the normal state in any population, including humans (Eastgate et al. 1988, Tovey et al. 1988). This low level of expression was only detected after very long exposure times in the present study. Previous studies showing no IL-1 $\beta$ in the normal testis of rats raised under standard laboratory conditions (Khan et al. 1987, Jonsson et al. 1999) may reflect differences in ongoing health status from population to population, as much as the relative sensitivity of the assay methods used.

In the present study, it was found that DEX was able to inhibit liver production of IL- $1 \beta$ in response to LPS as expected, but not in the testis. This observation suggests that the regulation of IL-1 $\beta$ production in the testis may be significantly different from that seen in other tissues. Glucocorticoids normally block inflammation by inhibiting the production of a number of pro-inflammatory mediators by monocyte/macrophages, lymphocytes and endothelial cells (Kapcala et al. 1995). IL-1 $\beta$, in particular, is regulated both transcriptionally and posttranscriptionally by glucocorticoids (Zuckerman et al. 1989, Scheinman et al. 1995). At this stage, the site of production of IL-1 $\beta$ in the rat testis is unknown. Evidence indicates that resident testicular macrophages in the rat do not produce significant amounts of either isoform of IL-1 in response to LPS stimulation (Kern et al. 1995, Hayes et al. 1996), although circulating leukocytes which may express IL-1 $\beta$ progressively increase in number within the testicular vasculature and interstitium following LPS treatment (O'Bryan et al. 2000). Sertoli cells, which produce IL-1 $\alpha$ constitutively, do not appear to produce IL-1 $\beta$, but rat and human Leydig cells express IL-1 $\beta$ in response to inflammatory stimulation in vitro (Lin et al. 1993, Cudicini et al. 1997, Jonsson et al. 1999). It is possible that, even though the Leydig cells possess glucocorticoid receptors 
(Stalker et al. 1989), the production of IL-1 $\beta$ by these cells may not be responsive to glucocorticoid control due to differences in the regulatory regions of the IL- $1 \beta$ gene, for example. Alternatively, the different effects of DEX on IL- $1 \beta$ mRNA in the testis and liver might be explained by differential access of DEX to the two organs. DEX is a substrate of P-glycoprotein, the product of the multi-drug resistance (Schinkel et al. 1995), which limits access of DEX to the brain and also appears to be expressed in the microvessels of the testis (Holash et al. 1993). Metabolism of DEX by this enzyme could account for the differences in the effect of DEX on IL-1 $\beta$ expression between the liver and testis. In either case, this tissue-specific difference in the response to DEX is deserving of further investigation.

In conclusion, these data clearly support a direct effect of LPS at the testis level, possibly even a direct effect of LPS on the Leydig cell itself, leading to acute inhibition of steroidogenesis. The secondary inhibition of testosterone production after LPS treatment seen at longer time-points, however, may occur in response to systemic inflammatory events, including the secretion of endogenous glucocorticoids. These data need to be taken into consideration when designing studies on the effects of inflammation on testicular function. These data also indicate a number of fundamental differences in the process of inflammation and its control in the rat testis, compared with other tissues. Finally, they have important implications for treatment of systemic or testicular inflammatory disease in subfertile or infertile patients, which may guide the appropriate use of glucocorticoids in such patients.

\section{Acknowledgements}

Thanks are due to Julie Muir and Kim Sebire for their expert technical assistance. M K O'B is the recipient of a Peter Doherty post-doctoral fellowship from the National Health and Medical Research Council of Australia. These studies were supported by grants from the National Health and Medical Research Council of Australia, and the Australian Research Council.

\section{References}

Adamopoulos DA, Lawrence DM, Vassilopoulos P, Contoyiannis PA \& Swyer GIM 1978 Pituitary-testicular interrelationships in mumps orchitis and other viral infections. British Medical Journal 1 1177-1180.

Bambino TH \& Hsueh AJ 1981 Direct inhibitory effect of glucocorticoids upon testicular luteinizing hormone receptor and steroidogenesis in vivo and in vitro. Endocrinology 108 2142-2148.

Bergh A \& Söder O 1990 Interleukin-1 $\beta$, but not interleukin-1 $\alpha$, induces acute inflammation-like changes in the testicular microcirculation of adult rats. Journal of Reproductive Immunology 17 155-165.

Bosmann HB, Hales KH, Li X, Liu Z, Stocco DM \& Hales DB 1996 Acute in vivo inhibition of testosterone by endotoxin parallels loss of steroidogenic acute regulatory (StAR) protein in Leydig cells. Endocrinology 137 4522-4525.

Bradbury MJ, Cascio CS, Scribner KA \& Dallman MF 1991 Stress-induced adrenocorticotropin secretion: diurnal responses and decreases during stress in the evening are not dependent upon corticosterone. Endocrinology 128 680-688.

Bradbury MJ, Akana SF \& Dallman MF 1994 Roles of type I and type II corticosteroid receptors in regulation of basal activity in the hypothalamic-pituitary-adrenal axis during the diurnal trough and peak: evidence for a nonadditive effect of combined receptor occupation. Endocrinology 134 1286-1296.

Buch JP \& Havlovec SK 1991 Variation in sperm penetration assay related to viral illness. Fertility and Sterility $\mathbf{5 5}$ 844-846.

Chomczynski P \& Sacchi N 1987 Single-step method of RNA isolation by acid guanidinium thiocyanate-phenol-chloroform extraction. Analytical Biochemistry 162 156-159.

Church GM \& Gilbert W 1984 Genomic sequencing. PNAS 81 1991-1995.

Cudicini C, Lejeune H, Gomez E, Bosmans E, Ballet F, Saez J \& Jégou B 1997 Human Leydig cells and Sertoli cells are producers of interleukins-1 and -6. Journal of Clinical Endocrinology and Metabolism 82 1426-1433.

Cumming D, Quigley M \& Yen SS 1983 Acute suppression of circulating testosterone levels by cortisol in men. Journal of Clinical Endocrinology and Metabolism 57 671-678.

Cutolo M, Balleari E, Giush M, Monachesi M \& Accardo S 1988 Sex hormone status of male patients with rheumatoid arthritis: evidence of low serum concentrations of testosterone at baseline and after human chorionic gonadotrophin stimulation. Arthritis and Rheumatism 31 1314-1317.

Del Punta K, Charreau CH \& Pignataro OP 1996 Nitric oxide inhibits Leydig cell steroidogenesis. Endocrinology 137 53375343.

Eastgate JA, Symons JA, Wood NC, Grinlinton FM, di Givone FS \& Duff GW 1988 Correlation of plasma interleukin 1 levels with disease activity in rheumatoid arthritis. Lancet ii (8613) 706-709.

Gao H, Shan L, Monder C \& Hardy MP 1996 Suppression of endogenous corticosterone levels in vivo increases the steroidogenic capacity of purified rat Leydig cells in vitro. Endocrinology 137 $1714-1719$.

Gomez F, de Kloet ER \& Armario A 1998 Glucocorticoid negative feedback on the HPA axis in five inbred rat strains. American Journal of Physiology 274 R420-R427.

Hales DB \& Payne AH 1989 Glucocorticoid-mediated repression of P450 scc mRNA and de novo synthesis in cultured Leydig cells. Endocrinology 124 2099-2104.

Hales DB, Xiong Y \& Tur-Kaspa I 1992 The role of cytokines in the regulation of Leydig cell P450c17 gene expression. Journal of Steroid Biochemistry 43 907-914.

Hayes R, Chalmers SA, Nikolic-Paterson DJ, Atkins RC \& Hedger MP 1996 Secretion of bioactive interleukin 1 by rat testicular macrophages in vitro. Journal of Andrology 17 41-49.

Holash JA, Harik SI, Perry G \& Stewart PA 1993 Barrier properties of testis microvessels. PNAS 90 11069-11073.

Imura H, Fukata J \& Mori T 1991 Cytokines and endocrine function: an interaction between the immune and neuroendocrine systems. Clinical Endocrinology 35 107-115.

Jonsson CK, Zetterström RH, Holst M, Parvinen M \& Söder O 1999 Constitutive expression of interleukin- $1 \alpha$ messenger ribonucleic acid in rat Sertoli cells is dependent upon interaction with germ cells. Endocrinology 140 3755-3761.

Kapcala LP, Chautard T \& Eskay RL 1995 The protective role of the hypothalamic-pituitary-adrenal axis against lethality produced by immune, infectious and inflammatory stress. Annals of the New York Academy of Sciences 771 419-437. 
Kern S, Robertson SA, Mau VJ \& Maddocks S 1995 Cytokine secretion by macrophages in the rat testis. Biology of Reproduction $\mathbf{5 3}$ 1407-1416.

Khan SA, Söder O, Syed V, Gustafsson K, Lindh M \& Ritzén EM 1987 The rat testis produces large amounts of an interleukin-1-like factor. International Journal of Andrology 10 495-503.

Khandjian EW \& Meric C 1986 A procedure for Northern blot analysis of native RNA. Analytical Biochemistry 159 227-232.

Lerman SA, Miller GK, Bohlman K, Albaladejo V, Leonard JF, Devas V \& Clark RL 1997 Effects of corticosterone on reproduction in male Sprague-Dawley rats. Reproductive Toxicology 11 799-805.

Li X, Youngblood GL, Payne AH \& Hales DB 1995 Tumor necrosis factor- $\alpha$ inhibition of $17 \alpha$-hydroxylase/C17-20 lyase (Cyp17) expression. Endocrinology 136 3519-3526.

Lin T, Wang D, Nagpal ML, Calkins JH, Chang W \& Chi R 1991 Interleukin-1 inhibits cholesterol side-chain cleavage cytochrome P450 expression in primary cultures of Leydig cells. Endocrinology 129 1305-1311.

Lin T, Wang D \& Nagpal ML 1993 Human chorionic gonadotropin induces interleukin-1 gene expression in rat Leydig cells in vivo. Molecular and Cellular Endocrinology 95 139-145.

Lin T, Wang D \& Stocco DM 1998 Interleukin-1 inhibits Leydig cell steroidogenesis without affecting steroidogenic acute regulatory protein messenger ribonucleic acid or protein levels. Journal of Endocrinology 156 461-467.

Ma XM \& Lightman SL 1998 The arginine vasopressin and corticotrophin-releasing hormone gene transcription responses to various frequencies of repeated stress in rats. Journal of Physiology 520 605-614.

Mauduit C, Gasnier F, Rey C, Chavin MA, Stocco DM, Louisot P \& Benahmed M 1998 Tumor necrosis factor- $\alpha$ inhibits Leydig cell steroidogenesis through a decrease in steroidogenic acute regulatory protein expression. Endocrinology 139 2863-2868.

Mock EJ, Norton HW \& Frankel AI 1978 Daily rhythmicity of serum testosterone concentration in the male laboratory rat. Endocrinology 103 1111-1121.

Monder C, Sakai RR, Miroff Y, Blanchard DC \& Blanchard RJ 1994 Reciprocal changes in plasma corticosterone and testosterone in stressed male rats maintained in a visible burrow system: evidence for a mediating role of testicular $11 \beta$-hydroxysteroid dehydrogenase. Endocrinology 134 1193-1198.

Nakano K, Suzuki S \& Oh C 1987 Significance of increased secretion of glucocorticoids in mice and rats injected with bacterial endotoxin. Brain, Behaviour and Immunity 1 159-172.

O'Bryan MK, Schlatt S, Phillips DJ, de Kretser DM \& Hedger MP 2000 Bacterial lipopolysaccharide-induced inflammation compromises testicular function at multiple levels in vivo. Endocrinology 141 238-246.

O’Donnell L, McLachlan RI, Wreford NG \& Robertson DM 1994 Testosterone promotes conversion of round spermatids between stages VII and VIII of the rat spermatogenic cycle. Endocrinology $1352608-2614$.

Ogilvie KM, Hales KH, Roberts ME, Hales DB \& Rivier C 1999 The inhibitory effect of intracerebroventricularly injected interleukin $1 \beta$ on testosterone secretion in the rat: role of steroidogenic acute regulatory protein. Biology of Reproduction 60 527-533.

Refojo D, Arias P, Moguilevsky JA \& Feleder C 1998 Effect of bacterial endotoxin on in vivo pulsatile gonadotrophin secretion in adult male rats. Neuroendocrinology 67 275-281.
Rivier C, Rivier J \& Vale W 1986 Stress-induced inhibition of reproductive functions: role of endogenous corticotropin-releasing factor. Science 231 607-609.

Saez JM, Morera AM, Haour F \& Evain D 1977 Effects of in vivo administration of dexamethasone, corticotropin and human chorionic gonadotropin on steroidogenesis and protein and DNA synthesis of testicular interstitial cells in prepuberal rats. Endocrinology 101 1256-1263.

Sapolsky RM 1985 Stress-induced suppression of testicular function in the wild baboon: role of glucocorticoids. Endocrinology 116 2273-2279.

Scheinman RI, Gualberto A, Jewell CM, Cidlowski JA \& Baldwin AS Jr 1995 Characterization of mechanisms involved in transrepression of NF- $\mathrm{\kappa B}$ by activated glucocorticoid receptors. Molecular and Cellular Biology 15 943-953.

Schinkel AH, Wagenaar E, van Deemter L, Mol CAAM \& Borst P 1995 Absence of the mdr1a P-glycoprotein in mice affects tissue distribution and pharmacokinetics of dexamethasone, digoxin, and cyclosporin A. Journal of Clinical Investigation 96 1698-1705.

Sharma AC, Sam AD II, Lee LY, Hales DB, Law WR, Ferguson JL \& Bosmann HB 1998 Effect of NG-nitro-L-arginine methyl ester on testicular blood flow and serum steroid hormones during sepsis. Shock 9 416-421.

Stalker A, Hermo L \& Antakly T 1989 Covalent affinity labeling, radioautography, and immunocytochemistry localize the glucocorticoid receptor in rat testicular Leydig cells. American Journal of Anatomy 186 369-377.

Stenzel-Poore M, Vale WW \& Rivier C 1993 Relationship between antigen-induced immune stimulation and activation of the hypothalamic-pituitary-adrenal axis in the rat. Endocrinology 132 1313-1318.

Sun YT, Wreford NG, Robertson DM \& de Kretser DM 1990 Quantitative cytological studies of spermatogenesis in intact and hypophysectomized rats: identification of androgen-dependent stages. Endocrinology 127 1215-1223.

Tovey MG, Content J, Gresser I, Gugenheim J, Blanchard B, Guymarho J, Poupart P, Gigou M, Shaw A \& Fiers W 1988 Genes for IFN- $\beta-2$ (IL-6), tumor necrosis factor, and IL-1 are expressed at high levels in the organs of normal individuals. Journal of Immunology 141 3106-3110.

Turnbull AV \& Rivier C 1997 Inhibition of gonadotropin-induced testosterone secretion by the intracerebroventricular injection of interleukin-1 $\beta$ in the male rat. Endocrinology 138 1008-1013.

Wallgren M, Kindahl H \& Rodriguez-Martinez H 1993 Alterations in testicular function after endotoxin injection in the boar. International Journal of Andrology 16 235-243.

Wolff S 1973 Biological effects of bacterial endotoxins in man. Journal of Infectious Diseases 128 5259-5264.

Zuckerman SH, Shellhaas J \& Butler 1989 Differential regulation of lipopolysaccharide-induced interleukin 1 and tumour necrosis factor synthesis: effects of endogenous and exogenous glucocorticoids and the role of the pituitary-adrenal axis. European Journal of Immunology 19 301-305.

Received 8 May 2000

Revised manuscript received 25 August 2000

Accepted 20 September 2000 